\title{
PRINSIP DAN STRATEGI KESANTUNAN PENULISAN DALAM ARTIKEL RUANGAN AGENDA BAHASA
}

\author{
Sara BEDEN \\ Jabatan Pengajian Melayu \\ Institut Pendidikan Guru Kampus Tun Abdul Razak, Sarawak, Malaysia \\ sara.beden@ipgmktar.edu.my
}

Manuscript received 1 Mar 2019

Manuscript accepted 9 June 2019

https://doi.org/10.33736/ils.1405.2019

\begin{abstract}
ABSTRAK
Kesantunan penulisan merujuk kepada kehalusan ketika menggunakan bahasa yang melibatkan penggunaan dan pemilihan kata, frasa, ayat dan ungkapan dalam penulisan. Aspek yang perlu diberi perhatian dalam kesantunan penulisan ialah penggunaan kata panggilan yang betul, pengaplikasian kata sapaan yang betul, gaya bahasa yang indah serta pemilihan kata dan ayat yang sesuai dengan konteks. Sementara topik dan isinya pula tidak menyentuh isu sensitif. Sehubungan itu, kajian ini bertujuan untuk menganalisis strategi kesantunan penulisan dalam artikel Ruangan Agenda Bahasa dalam majalah Dewan Bahasa terbitan Julai 2018. Kajian ini mengaplikasikan tiga model kesantunan, iaitu Leech (1983), Grice, 1975) dan Asmah Omar (2000) yang membentuk pola kombinasi maksim + strategi. Kajian ini merupakan kajian kualitatif dengan memberikan fokus kepada analisis teks. Dapatan menunjukkan AR1 memperlihatkan pematuhan terhadap maksim Kebijaksanaan + Sokongan + Kualiti + Relevan + Kepatuhan pada Tajuk + Penjagaan Air Muka manakala AR2 pula mematuhi maksim Kebijaksanaan + Sokongan + Kualiti + Cara + Kepatuhan pada Tajuk + Penjagaan Air Muka. Dapatan ini merefleksikan bahawa kedua-dua penulis dalam ruangan agenda bahasa mematuhi peraturan penulisan dengan tidak mengabaikan aspek kesantunan berbahasa. Kesimpulannya, pematuhan penulis artikel terhadap aspek kesantunan penulisan memanifestasikan penulis dalam bidang akademik tidak meminggirkan inisiatif untuk melestarikan budaya santun.
\end{abstract}

Kata kunci: strategi kesantunan, isu sensitif, pola kombinasi maksim, kepatuhan, penjagaan air muka 


\title{
PRINCIPLES AND STRATEGIES OF WRITING POLITENESS IN ARTICLES OF THE AGENDA BAHASA COLUMN
}

\begin{abstract}
Writing politeness refers to the refinement when using a language that involves the use and selection of words, phrases, sentences and expressions in writing. The aspect that needs to be addressed in writing politeness is the use of correct vocation, application of correct salutation, aesthetic language style, as well as selection of words and sentences that is appropriate with context. The topic and contents, however, are not touching on any sensitive issues. In this regard, the study aims to analyse the writing politeness strategy in the article of Agenda Language column from Dewan Bahasa magazine, July 2018 issue. This study applied three models of politeness, namely, Leech (1983), Grice (1975) and Asmah Omar (2000) that form the maxim combination pattern + strategy. . This study is a qualitative study focusing on textual analysis. The findings show that AR1 demonstrates compliance with Maxim of Wisdom + Support + Quality + Relevance + Adherence to Title + Safeguard of personal honour while AR2 complies with Maxim of Wisdom + Support + Quality + Method + Adherence to Title + Safeguard of personal honour. This finding reflects that both writers in the language agenda column comply with the written rules by not neglecting aspects of language politeness. In conclusion, this shows that writers in the academic field do not neglect the initiative to preserve a culture of politeness.
\end{abstract}

Keywords: politeness strategy, sensitive issues, maxim combination pattern, compliance, safeguard of personal honour

\section{Pengenalan}

Bahasa merupakan wadah, wahana atau alat komunikasi yang paling berkesan dalam sesebuah komuniti sehingga bahasa diibarat melambangkan bangsa. Sesebuah bangsa dikenali menerusi gaya dan lenggok bahasanya kerana bahasa ialah pakaian fizikal yang dapat diperhati, diteliti dan dihakimi dengan mata kasar oleh lingkungan di sekelilingnya. Bahasa yang diucap atau diujarkan oleh seseorang bukan sahaja dapat mencermin dan mencitrakan kehemahannya malahan dapat menyingkap dasar keperibadian dan kehalusan budi bicaranya. Hashim Ahmad (2016, hlm. 12) dalam makalah yang bertajuk "Bahasa Menggambarkan Peribadi" menegaskan bahawa bahasa yang diucapkan oleh seseorang itu menggambarkan latar akhlak masyarakat asalnya kerana bahasa merupakan warisan bangsa. Pandangan ini merupakan suatu representasi bahawa sebelum mengujar atau menyatakan sesuatu, unsur-unsur bahasa sewajarnya dipilih agar tepat, sesuai dan betul penggunaannya mengikut konteks supaya tidak mencalar dan menggores perasaan pihak lain. Ujaran atau pertuturan yang dizahirkan oleh seseorang dapat mencerminkan peribadi mahupun adabnya dalam berbahasa, sekali gus mewakili komunitinya. Oleh itu, perilaku dan adab dalam berkomunikasi sewajarnya dipelihara dan tidak boleh dipandang remeh. 
Pendeta Zainal Abdidin Ahmad (1950) pernah berkongsi etiket dan perlakuan yang harus dipraktis dalam kehidupan seharian dengan turut memberikan penekanan terhadap tatacara berbahasa. Beliau menegaskan bahawa kelantangan suara perlu dikawal semasa berkomunikasi kerana kita tidak perlu menjerit untuk menyampaikan perkara yang hendak dibicarakan kepada orang lain. Sifat merendah diri pula sewajarnya menjadi perhiasan peribadi agar sentiasa disenangi orang yang berada di sekeliling kita. Sikap ini juga merupakan kunci pembawaan diri yang mustajab untuk berlaku sopan walau di ceruk mana seseorang itu berada kerana sikap menunjuk-nunjuk akan mengakibatkan pihak di sekeliling kita berasa meluat malahan benci. Oleh itu, sikap berhati-hati dengan mengambil kira faktor siapa lawan bicara, konteks dan tujuan dalam berkomunikasi perlu diberi keutamaan agar tiada pihak yang tersinggung mahupun tercalar maruahnya.

Robert Sibarani (2004, hlm. 216) berpendapat bahawa kesopanan berbahasa tercermin dalam tatacara berkomunikasi. Menurut beliau lagi, dalam berkomunikasi kita harus menghormati dan menyesuaikan norma-norma budaya dalam masyarakat. Jika berlaku sebaliknya, maka seseorang boleh dianggap sombong, tidak beradab malahan tidak berbudaya. Pandangan ini memperjelas bahawa tatacara berkomunikasi amat signifikan dan dititikberatkan dalam budaya masyarakat kerana dapat mencerminkan keperibadian selain mampu menggendalakan kelancaran komunikasi. Apabila komunikasi tergendala, perkara ini bukan sahaja menjejaskan pemahaman terhadap maklumat yang hendak disampaikan malahan mempengaruhi keberkesanan dalam komunikasi. Justeru, pematuhan terhadap tatacara berkomunikasi secara langsung akan mencitrakan kesopanan berbahasa sekali gus melancar dan mengharmoniskan komunikasi.

Tenas Effendy (2011, hlm. 1) menyatakan bahawa kesopanan menjadi asas kejatidirian Melayu yang terpuji sebagaimana dalam ungkapan adat Melayu, iaitu "berbuah kayu rendang daunnya, bertuah Melayu terbilang santunnya, elok kayu kerana daunnya, elok Melayu kerana santunnya". Pandangan Tenas Effendy ini sejalur dengan gagasan Leech (1983) dalam Prinsip Kesopanan, iaitu memberikan penekanan terhadap tatacara, adab dan sopan dalam berkomunikasi agar kesopanan terpelihara sekali gus tidak menyinggung perasaan mana-mana pihak. Tenas Effendy (2011, hlm. 5) dalam karyanya Kesantunan dan Semangat Melayu memerihalkan kesopanan atau kesantunan sebagai perilaku yang "tahu diri" atau "sedar diri", yakni perilaku yang mencerminkan kearifan dan kebijaksanaan dalam menilai dan mengukur kemampuan diri agar dapat menempatkan dirinya secara baik dan benar dalam kehidupan berumahtangga, bermasyarakat, berbangsa dan bernegara. Pandangan ini memanifestasikan bahawa aspek kesantunan amat signifikan dalam semua bentuk komunikasi sama ada secara lisan, tulisan, verbal dan nonverbal. Kesantunan dalam penulisan diberi penegasan oleh Sara Beden dan Indirawati Zahid (2014, hlm. 152) dengan menyatakan bahawa aspek kesopanan berbahasa bukan sahaja signifikan dalam penggunaan bahasa yang bersifat lisan semata-mata malahan memainkan peranan yang penting dalam penggunaan bahasa yang bersifat tulisan agar menjadi wadah yang berkesan untuk mentarbiah generasi muda. Tambahan pula, penulisan yang bermutu tidak akan meminggirkan aspek kesopanan berbahasa sebagai cerminan keintelektualan pengarangnya. 
Kesantunan penulisan bermaksud kesopanan dan kehalusan ketika menggunakan bahasa yang melibatkan penggunaan dan pemilihan kata, frasa atau ungkapan dan ayat dalam penulisan (Sara Beden, 2018, hlm. 55). Aspek kesantunan yang perlu diberi perhatian dalam kesantnan penulisan ialah penggunaan kata panggilan yang betul, pengaplikasian kata sapaan yang betul, gaya bahasa yang tepat serta pemilihan kata dan ayat yang sesuai dengan konteks dan isi yang tidak menyentuh isu sensitif. Interaksi atau komunikasi bertulis merupakan suatu proses untuk menyampai dan menerima idea-idea serta maklumat daripada satu pihak kepada pihak yang lain secara bertulis. Penulisan ditakrifkan sebagai perihal atau kegiatan menulis (mengarang) dan lain-lain (Kamus Dewan Edisi Ketiga, 2000). Menurut Abdullah Hassan (2006, hlm. 79), gaya komunikasi yang utama dalam pengurusan ialah perkataan bertulis. Syarat utama dalam menulis ialah semua tulisan hendaklah ringkas, mudah dan mempunyai perkataan, ayat serta idea yang baik.

Dalam konteks kesantunan penulisan, beberapa faktor turut mempengaruhinya. Antaranya ialah tahap pendidikan, iaitu orang yang berpendidikan tinggi lazimnya lebih mengamalkan kesantunan berbahasa kerana mereka terdedah dengan ilmu pengetahuan tentang kesantunan berbahasa melalui pembacaan yang luas dan peka dengan pemilihan dan penggunaan bahasa berdasarkan konteks yang relevan. Aspek kesantunan juga ditandai dengan penggunaan bahasa yang gramatis, tepat dan betul dalam setiap hasil penulisan. Selain itu, pemilihan dan penggunaan frasa yang menarik dan sesuai dapat membantu penulis untuk menghasilkan sebuah penulisan yang menarik dan berkualiti. Setiap penulisan perlu mematuhi format dan peraturan penulisan. Permulaan, isi dan pengakhiran penulisan yang sempurna harus diberi penekanan dan dititikberatkan dalam kesantunan penulisan. Ketiga-tiga bahagian ini perlu ditulis dengan menggunakan bahasa yang sopan, lemah lembut, berbudi bahasa yang tinggi di samping mematuhi peraturan linguistik, sosiolinguistik dan pragmatik. Peraturan linguistik menitikberatkan ketepatan bentuk dan binaan sesuatu bahasa termasuk sebutan, intonasi dan tatabahasa manakala peraturan sosiolinguistik pula memberikan fokus terhadap aspek ketertiban dalam hubungan sosial antara penulis dan pembaca dalam bidang penulisan atau antara pembicara dan lawan bicara dalam komunikasi tatap muka. Yule (1996, hlm. 4) mengutarakan empat medan yang boleh dikaitkan dengan konsep pragmatik, iaitu kajian makna, kajian makna menurut konteks, bidang yang melebihi kajian makna dan kajian tentang bentuk ekspresi. Justeru, peraturan pragmatik menitikberatkan penggunaan bahasa yang sopan dan berkesan, pengguna serta penggunaannya dan konteks atau situasi agar hasrat komunikasi tercapai. Ketiga-tiga peraturan ini dikombinasi dalam menghasilkan wacana yang bukan sahaja utuh, runtut dan bertaut malah memiliki kesatuan selain terpelihara kesantunannya.

Selain itu, penggunaan gaya bahasa yang indah seperti bahasa kiasan menerusi ungkapan kata-kata yang melibatkan pengolahan idea juga perlu diberi perhatian. Bahasa kiasan menjadi rencah dan resepi yang melengkap, menguat, mengukuh, melembutkan ungkapan dan menjadikan maksud lebih jelas selain bertindak sebagai perhiasan yang "mencantikkan" bahasa dalam sesebuah wacana yang mantap. Berdasarkan sorotan, didapati kesantunan penulisan tidak hanya 
dibatasi oleh tatabahasa semata-mata tetapi turut mementingkan penggunaan kata ganti nama yang sesuai bertitik tolak atas faktor perkara ini berupaya menggambarkan penulisnya seorang yang berperibadi mulia dan bersopan santun. Penulis yang berhemah tinggi akan berusaha menyantuni pembaca selain memiliki tahap pendidikan yang tinggi.

Sehubungan itu, kajian ini diharap dapat menambah khazanah dalam bidang pragmatik khususnya dalam aspek kesopanan berbahasa dalam bidang penulisan dengan menggunakan artikel yang diterbitkan oleh Dewan Bahasa dan Pustaka. Kepentingan bidang pragmatik ini dapat dikesan melalui pandangan Zaitul Azma Zainon Hamzah (2009, hlm. 30) yang memberi penegasan bahawa aspek kecekapan pragmatik perlu diterapkan kerana kecekapan pragmatik dapat menyerlahkan penggunaan bahasa sebagai aksi sosial, mewakili hajat seseorang dalam komunikasi.

Makalah ini memperincikan strategi kesantunan yang diaplikasi pengarang dalam artikel Ruangan Agenda Bahasa dalam majalah Dewan Bahasa terbitan Julai 2018. Data korpus dianalisis dengan menggunakan kombinasi tiga model pendekatan, iaitu Prinsip Kesopanan Leech (1983), Prinsip Kerjasama Grice (1975) dan Strategi Kesantunan Asmah Omar (1966, 2000). Leech (1983) mengetengahkan enam maksim dan diklasifikasikan kepada empat skala, iaitu skala Kos-Manfaat, skala Pujian-Cacian, skala Persetujuan dan skala Simpati. Sementara model Grice (1975) pula mengutarakan empat maksim, iaitu Maksim Kuantiti, Kualiti, Relevan dan Cara. Model Asmah (2000) pula mengemukakan strategi kesantunan dalam berbahasa yang perlu dipatuhi bagi memelihara kesantunan. Justeru, kajian ini dapat memperlihatkan aspek kesopanan berbahasa yang signifikan pada aras pemikiran yang lebih tinggi secara terperinci sebagaimana yang diaplikasikan oleh penulis artikel dalam ruangan agenda bahasa sekali gus berupaya memberikan panduan kepada para penulis dalam bidang penulisan ilmiah.

\section{Objektif Kajian}

Kajian ini bertujuan menganalisis aspek kesantunan berbahasa dalam penulisan artikel ruangan agenda bahasa dengan mengaplikasikan Prinsip Kesopanan Leech (1983), Prinsip Kerjasama Grice (1975) dan Strategi Kesantunan Asmah Omar (2000).

\section{Pendekatan Kajian dan Metodologi}

Kajian ini mengaplikasikan kaedah kepustakaan dan kaedah analisis teks. Kaedah kepustakaan melibatkan pembacaan dan pengumpulan bahan-bahan ilmiah sebagai sumber rujukan. Data korpus yang digunakan dalam kajian ini merupakan dua buah artikel daripada ruangan agenda bahasa yang bertajuk "Perjuangan Bahasa Melayu di Tangan Anak Muda" hasil tulisan Mohamad Syafiq Rohaizad Buyong (2018, hlm. 10-14) dan "Perjuangan yang masih berliku" tulisan Amirah Syazwani Baderol Sham (2018, hlm. 6-9) dalam Majalah Dewan Bahasa terbitan Dewan Bahasa dan Pustaka keluaran bulan Julai 2018. "Perjuangan Bahasa Melayu di Tangan Anak Muda" dikodkan sebagai AR1 yang merujuk kepada artikel pertama. Sementara artikel yang bertajuk "Perjuangan yang masih berliku" dikodkan sebagai AR2, iaitu merujuk kepada artikel yang kedua sebagaimana dalam jadual 1 berikut. 
Jadual 1

Artikel ruangan Agenda Bahasa

\begin{tabular}{lcc}
\hline \multicolumn{1}{c}{ Artikel } & Halaman & Kod \\
\hline Perjuangan Bahasa Melayu di Tangan Anak Muda & $10-13$ & AR1 \\
\hline Perjuangan yang masih berliku & $6-9$ & AR2 \\
\hline
\end{tabular}

Artikel-artikel ini dimuatkan dalam Ruangan Agenda Bahasa dalam "Majalah Dewan Bahasa" yang merupakan ruangan tetap dan setiap keluaran. Bahan ini dipilih sebagai data korpus kerana artikel-artikel dalam ruangan ini menyajikan agenda-agenda dan isu-isu bahasa yang "segar" dan relevan sebagai wadah bacaan kepada semua khalayak pembaca tanpa mengira peringkat umur dan status. Lanjutan itu, kajian kesantunan berdasarkan isu yang menjadi medan perbincangan dalam korpus ini berupaya membuktikan bahawa artikel-artikel ini bersesuaian dan relevan sebagai bahan bacaan arus perdana atas faktor memenuhi tuntutan ciri-ciri penulisan ilmiah sekali gus menjadi panduan kepada penulis-penulis lain.

Seterusnya, data-data dikod berdasarkan bilangan artikel, halaman dan perenggan. Misalnya, AR1/H10/P3, iaitu AR1 merujuk kepada artikel 1, H10 merujuk kepada halaman sepuluh dan P3 pula merujuk kepada perenggan tiga dan seterusnya bagi AR2 yang merujuk kepada artikel kedua. Pengekodan dilakukan adalah untuk memudahkan proses pengenalpastian data analisis.

Kaedah analisis teks dilakukan dengan mengenal pasti unsur-unsur bahasa yang digunakan oleh penulis dalam kedua-dua artikel yang berpadanan dengan maksim-maksim Prinsip Kesopanan Leech (1983), Prinsip Kerjasama Grice (1975) dan strategi kesantunan Asmah Haji Omar (1996, 2000). Padanan data-data dengan maksim-maksim dan strategi kesantunan Asmah Haji Omar dilakukan dengan memberikan fokus terhadap penggunaan kata, ungkapan atau frasa, ayat dan tajuk yang berpadanan dengan model-model kesantunan tersebut. Prinsip Kesopanan Leech memberi penekanan kepada perilaku dan persoalan beradab yang menghubungkan dua pihak dalam sesuatu proses komunikasi, yakni penutur dan pendengar. Leech $(1993, \mathrm{hlm}$. 158) telah mengutarakan enam maksim, iaitu Kebijaksanaan, Kedermawanan, Sokongan, Kerendahan Hati, Persetujuan dan Simpati menerusi PS bagi menggambarkan kesopanan sebagaimana dalam paparan Jadual 2: 
Jadual 2

Model Prinsip Kesantunan Leech (1983)

\begin{tabular}{ll}
\hline \multicolumn{1}{c}{ Maksim } & \multicolumn{1}{c}{ Spesifikasi } \\
\hline Kebijaksanaan (Tact) & $\begin{array}{l}\text { Maksim yang meminimumkan kos bagi orang lain dan } \\
\text { memaksimumkan manfaat kepada orang lain. }\end{array}$ \\
\hline Kedermawanan (Generosity) & $\begin{array}{l}\text { Maksim yang meminimumkan manfaat bagi diri sendiri } \\
\text { dan memaksimumkan kos bagi diri sendiri atau dengan } \\
\text { kata lain menguntungkan orang lain. }\end{array}$ \\
\hline Sokongan (Approbation) & Maksim yang meminimumkan cacian terhadap orang \\
\hline Kerendahan Hati (Modesity) & Maksim yang meminimumkan pujian terhadap diri \\
& $\begin{array}{l}\text { sendiri dan memaksimumkan cacian terhadap diri } \\
\text { sendiri. }\end{array}$ \\
\hline Persetujuan (Agreement) & Maksim yang meminimumkan perbalahan antara diri \\
& sendiri dengan orang lain dan memaksimumkan \\
& persetujuan antara diri sendiri dengan orang lain bagi \\
& mencapai kesepakatan. \\
\hline Simpati (Sympathy) & Maksim yang meminimumkan antipati antara diri sendiri \\
& dengan orang lain dan memaksimumkan simpati antara \\
& diri sendiri dengan orang lain.
\end{tabular}

Sementara Grice (1975) telah mengemukakan Prinsip Kerjasama untuk memperlihatkan kerjasama. Secara umumnya Prinsip Kerjasama Grice ialah prinsip atau tatacara yang perlu dipatuhi oleh penutur dan pendengar dalam perbualan mereka untuk menghasilkan komunikasi yang berkesan dengan kewujudan kerjasama kedua-dua belah pihak yang terlibat dalam perbualan. Grice (1975, hlm. 47) mengetengahkan empat maksim, iaitu Kuantiti, Kualiti, Relevan dan Cara sebagaimana paparan jadual 3 berikut:

Jadual 3

Prinsip Kerjasam Grice (1975)

\begin{tabular}{|c|c|}
\hline Maksim & Spesifikasi \\
\hline Kuantiti & $\begin{array}{l}\text { Bermaksud memberi maklumat yang sempurna, iaitu merujuk kepada } \\
\text { pemberian maklumat yang informatif dan mencukupi dan tidak } \\
\text { memberikan maklumat yang berlebihan daripada yang diperlukan } \\
\text { dalam komunikasi. }\end{array}$ \\
\hline Kualiti & $\begin{array}{l}\text { Bermaksud memberikan maklumat yang betul, iaitu tidak menyebut } \\
\text { sesuatu yang anda tidak tahu atau benar dan tidak menyebut sesuatu } \\
\text { yang anda tidak tahu dalil atau kesahihan buktinya. }\end{array}$ \\
\hline Relevan & $\begin{array}{l}\text { Bermaksud maklumat yang mempunyai pertalian atau ciri-ciri yang } \\
\text { rapat, iaitu maklumat yang disampaikan haruslah berkaitan sama ada } \\
\text { tersurat atau tersirat. }\end{array}$ \\
\hline Cara & $\begin{array}{l}\text { Bermaksud menyatakan sesuatu dengan cara yang betul dan mudah } \\
\text { difahami bagi mengelakkan maklumat yang memperlihatkan } \\
\text { ketaksaan, kekaburan dan berbelit-belit. }\end{array}$ \\
\hline
\end{tabular}


Seterusnya, Asmah Omar $(1996,2000)$ telah mengemukakan model kesopanan dengan membahagikannya kepada Kesopanan Asas dan Kesopanan Berkendala. Asmah Omar memerihalkan Kesopanan Asas merujuk pada kesopanan sedia ada yang menjadi pedoman kepada ahli masyarakat untuk berhubung antara satu sama lain dengan cara menunjukkan sikap berbaik-baik antara mereka manakala Kesopanan Berkendala merupakan usaha yang dilakukan dalam sesuatu interaksi dengan memberi perhatian pada kendala-kendala tertentu. Kesopanan Berkendala menekankan perhatian terhadap peranan sosial pemeran, latar, judul percakapan, sebab dan cara percakapan serta penyesuaian peraturan- pertuturan dengan keadaan ini secara sedar (Asmah Omar, 1996, hlm. 91). Bagi Asmah Omar, hal ini tidak bermakna Kesopanan Asas tidak memberi pertimbangan terhadap kendala-kendala tersebut. Dalam hal ini, peraturan dalam pertuturan tersebut diterapkan secara spontan tanpa perlu memikirkan kendala-kendala itu dengan lama. Oleh itu, Asmah Omar (2000, hlm. 91) merumuskan bahawa Kesopanan Berkendala letaknya di atas dan melebihi Kesopanan Asas.

Asmah Omar turut memasukkan strategi komunikasi dalam model beliau tetapi strategi komunikasi ini berbeza dengan strategi-strategi dalam model Brown dan Levinson (1987) kerana strategi komunikasi kedua-dua sarjana Barat tersebut bermotif untuk mencapai keinginan-keinginan tertentu. Bagi Asmah Omar (1996, hlm. 92) kesopanan bukanlah strategi semata-mata tetapi kesopanan merupakan ciri budaya yang menuntut ahli masyarakat bersopan santun dan menghormati antara satu sama lain. Asmah juga berpandangan bahawa Kesopanan Asas ada perkaitannya dengan didikan awal yang diterima oleh seseorang manakala kesopanan sebagai strategi merupakan tambahan kepada Kesopanan Asas. Oleh itu, Asmah Omar (1996) menyimpulkan bahawa Kesopanan Berkendala sebagai Kesopanan Asas yang disertai dengan strategi komunikasi (KA+S) seperti dalam Rajah 1 berikut:

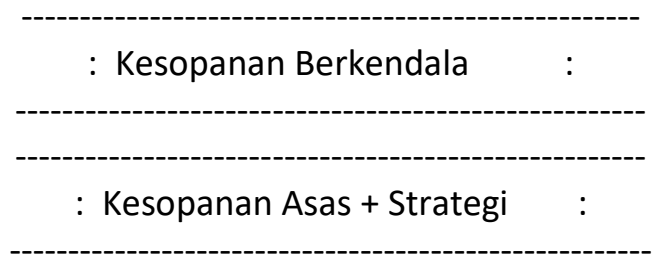

Rajah 1. Model Kesantunan Asmah Omar (1996) (Kesopanan Asas + Strategi (KA+S))

Kesopanan Asas + Strategi $(K A+S)$ merupakan kaedah yang digunakan oleh pemeran untuk mencapai tujuan dalam komunikasi dan strategi komunikasi yang menandai kesopanan melibatkan enam strategi berikut. Pertama, ialah pengakuan adanya perkaitan peranan antara pemeran. Asmah Omar (1996) menjelaskan perkaitan peranan menghendaki pemeran bukan setakat menjalankan peranan dan mematuhi peraturan giliran berkomunikasi tetapi juga mengakui peranan yang dijalankan oleh pemeran lain. Kedua, kesedaran akan adanya perbezaan taraf sosial antara pemeran yang merujuk kepada perbezaan taraf sosial pula akan lebih disedari akibat wujudnya pertemuan bersemuka. Ketiga, kesedaran akan adanya kuasa pada 
peranan dan taraf tertentu, iaitu Asmah Omar (1996, hlm. 100) menjelaskan bahawa kewujudan kuasa ialah akibat pengakuan terhadap perkaitan peranan dan perbezaan taraf sosial yang terdapat pada peranan dan taraf tertentu. Strategi keempat pula merujuk kepada menjaga air muka. Asmah Omar (1996) turut menjelaskan bahawa air muka dalam budaya Melayu tidak sama dengan pengertian "muka" yang diutarakan oleh Brown dan Levinson (1987). Air muka mempunyai peranan bukan setakat masa berlangsungnya sesuatu komunikasi tetapi menjangkau ruang lingkup yang lebih daripada itu. Dalam berkomunikasi, seseorang itu harus berhati-hati supaya tidak ada air muka yang tercemar sama ada air muka diri sendiri atau orang lain. Kelima ialah kepatuhan pada tajuk atau bidang perbincangan atau perbahasan. Asmah Omar (1996, hlm. 102) memberikan penegasan bahawa kepatuhan kepada tajuk atau bidang perbincangan atau perbahasan merupakan salah satu ciri kesopanan dalam peristiwa bahasa. Penyimpangan daripada tajuk dan bidang menyebabkan ketergendalaan dari segi masa dan menimbulkan kekeliruan dalam perbincangan sesuatu peristiwa bahasa. Keenam, merujuk kepada kepatuhan pada peraturan mesyuarat. Peraturan dalam mesyuarat, forum, seminar dan sebagainya meliputi giliran dan jangka masa berucap. Walau bagaimanapun, strategi kesantunan Asmah Haji Omar yang berkaitan sahaja akan diaplikasi dalam kajian ini bagi meneliti strategi kesantunan yang digunakan oleh penulis.

Ketiga-tiga model ini diaplikasi sebagai landasan analisis atas faktor gabungan ini berupaya memperincikan aspek kesantunan berbahasa dengan lebih holistik. Penggabungan ini juga berupaya memperlihatkan variasi kesantunan yang diaplikasikan oleh penulis dalam usaha menghaluskan komunikasi khususnya dalam penulisan. Sara Beden dan Indirawati Zahid $(2015, \mathrm{hlm}$. 61) mendapati bahawa kombinasi model kesopanan Leech dan model kerjasama Grice berupaya memanifestasikan kesopanan berbahasa dengan jelas dan wujudnya pola-pola kombinasi maksim. Walau bagaimanapun, kedua-dua model tersebut didapati ada kekurangannya dalam menganalisis data korpus yang berkaitan dengan kepatuhan pada tajuk dan strategi penjagaan air muka sebagaimana yang diberi penekanan dalam model Asmah Omar (1996, 2000). Kekurangan ini menjadi titik tolak kepada penggabungan ketiga-tiga model tersebut sebagai kerangka analisis. Kombinasi ketiga-tiga model ini juga dilakukan setelah mengambil kira faktor keupayaan maksim-maksim dalam Prinsip Kesantunan Leech (1983) dan Prinsip Kerjasama Grice (1975) tidak sepenuhnya dapat dipadankan dengan korpus kajian dan memerlukan kombinasi model kesopanan Asmah (1996) dalam kasus-kasus tertentu.

\section{Dapatan Analisis}

Berdasarkan analisis, dapatan memperlihatkan pembentukan pola kombinasi maksim ditambah dengan strategi. Pola kombinasi maksim ditunjukkan menerusi pengaplikasian maksim-maksim PS Leech dan PK Grice manakala strategi diperlihatkan menerusi penggunaan strategi kesantunan Asmah Haji Omar. Dapatan ini terdapat dalam Jadual 4 berikut. 
Jadual 4

Dapatan kajian

\begin{tabular}{|c|c|c|}
\hline Strategi & Artikel & Pola kombinasi maksim + Strategi \\
\hline $\begin{array}{l}\text { Prinsip } \\
\text { Kesantunan }\end{array}$ & AR1 & $\begin{array}{l}\text { Kebijaksanaan + Sokongan + Kualiti + Relevan + Strategi } \\
\text { Kepatuhan pada Tajuk + Strategi Penjagaan Air Muka }\end{array}$ \\
\hline $\begin{array}{l}\text { Leech/ Prinsip } \\
\text { Kerjasam Grice/ } \\
\text { Strategi } \\
\text { kesantunan } \\
\text { Asmah Haji } \\
\text { Omar }\end{array}$ & AR2 & $\begin{array}{l}\text { Kebijaksanaan + Sokongan + Kualiti + Cara + Strategi } \\
\text { Kepatuhan pada Tajuk + Strategi Penjagaan Air Muka }\end{array}$ \\
\hline
\end{tabular}

Dapatan kajian menunjukkan kedua-dua artikel yang digunakan sebagai bahan kajian memperlihatkan pengaplikasian ketiga-tiga strategi kesantunan, iaitu Prinsip Kesantunan Leech, Prinsip Kerjasam Grice dan strategi kesantunan Asmah Haji Omar yang membentuk pola kombinasi maksim + strategi. AR1 memperlihatkan pematuhan terhadap maksim Kebijaksanaan + Sokongan + Kualiti + Relevan + Kepatuhan pada Tajuk + Penjagaan Air Muka manakala AR2 pula mematuhi maksim Kebijaksanaan + Sokongan + Kualiti + Cara + Kepatuhan pada Tajuk + Penjagaan Air Muka. Dapatan ini menunjukkan bahawa kedua-dua penulis dalam ruangan agenda bahasa mematuhi peraturan penulisan dengan tidak mengabaikan aspek kesantunan. Kedua-dua artikel menunjukkan pengaplikasian maksim yang sama cuma perbezaannya kewujudan maksim Relevan dalam AR1 dan maksim Cara dalam AR2. Pengaplikasian strategi kesantunan Asmah Haji Omar pula memperlihatkan persamaan, iaitu pengaplikasian strategi Kepatuhan pada Tajuk dan strategi Penjagaan Air Muka. Perkara ini menzahirkan bahawa kedua-dua penulis berusaha untuk menyantuni semua khalayak pembaca melalui penyampaian maklumat yang mematuhi topik perbincangan dan tindakan untuk menjaga air muka mana-mana pihak. Penggunaan aspek kesantunan dalam komunikasi bertulis menjadikan maklumat yang disampaikan lebih santun dan berhemah, memberikan manfaat kepada pembaca, mematuhi tatacara berbahasa, berkualiti, runtut, bertaut, jelas serta berkaitan selain mematuhi tajuk dan mementingkan penjagaan air muka. Sara Beden dan Indirawati Zahid (2016, hlm. 68) menegaskan bahawa pembudayaan dan penggunaan bahasa yang bercirikan kesopanan sudah tentu dapat melahirkan masyarakat yang berbudi bahasa dan tahu menggunakan bahasa di samping memiliki kepekaan untuk menyesuaikannya dengan pelbagai situasi.

\section{Perbincangan Analisis}

Perbincangan analisis dalam makalah ini dipapar berdasarkan AR1 dan seterusnya AR2 untuk memperlihatkan pola kombinasi maksim + strategi kesantunan yang digunakan oleh kedua-dua penulis. 


\section{Perjuangan Bahasa Melayu di Tangan Anak Muda (AR1)}

Berdasarkan analisis terhadap AR1, didapati artikel ini menunjukkan pengaplikasian pola kombinasi maksim + strategi, iaitu Kebijaksanaan + Sokongan + Kualiti + Relevan + Kepatuhan pada Tajuk + Penjagaan Air Muka sebagaimana paparannya dalam Jadual 5 berikut.

Jadual 5

Pola kombinasi maksim + strategi, iaitu Kebijaksanaan + Sokongan + Kualiti + Relevan + Kepatuhan pada Tajuk + Penjagaan Air Muka

\begin{tabular}{|c|c|c|}
\hline AR1/halaman & Artikel & $\begin{array}{c}\text { Pola Pola } \\
\text { kombinasi maksim } \\
+ \text { strategi }\end{array}$ \\
\hline AR1/H12/P1 & $\begin{array}{l}\text {... dalam ikhtiar kita mengangkat martabat } \\
\text { bahasa Melayu, kita sebenarnya } \\
\text { memerlukan jalinan kerjasama serta buah } \\
\text { fikiran daripada generasi muda. }\end{array}$ & \\
\hline AR1/H13/P3 & $\begin{array}{l}\text { Seharusnya kita mengambil peluang } \\
\text { daripada kecanggihan teknologi dan } \\
\text { memanfaatkan kemajuan yang dikecapi } \\
\text { oleh negara untuk mengembangkan bahasa } \\
\text { Melayu. Golongan muda harus bersedia dari } \\
\text { segi minda dan tenaga untuk mengambil } \\
\text { alih peranan yang dimainkan golongan } \\
\text { muda terdahulu dan bersiap siaga dari segi } \\
\text { ilmu untuk menggalas tanggungjawab ini } \\
\text { demi kelangsungan dan kegemilangan } \\
\text { bahasa Melayu sebagai bahasa ilmu. }\end{array}$ & \\
\hline AR1/H13/P1 & $\begin{array}{l}\text { Sultan al-Fatih yang berjaya menawan kota } \\
\text { Constantinopel pada usia } 21 \text { tahun, Usaman } \\
\text { bin Zalid yang berjaya mengetuai angkatan } \\
\text { tentera Islam ke wilayah Syam pada usia } 18 \\
\text { tahun, Imam Syafiee yang layak } \\
\text { mengeluarkan fatwa di Mekah pada usia } 15 \\
\text { tahun dan Imam al-Ghazali yang sudah } \\
\text { menjadi ilmuwan terkemuka pada usia } 20 \\
\text { tahun. }\end{array}$ & Kebijaksanaan \\
\hline AR1/H13 & $\begin{array}{l}\ldots \text { pejuang bahasa } \\
\ldots \text { pencinta bahasa } \\
\ldots \text { pelopor perjuangan } \\
\ldots \text { generasi terdahulu } \\
\ldots \text { generasi pewaris }\end{array}$ & \\
\hline AR1/H11/P4 & $\begin{array}{l}\text { Sejarah tetap terpahat dan kita sebagai } \\
\text { generasi pewaris sesungguhnya perlu } \\
\text { berterima kasih kepada generasi terdahulu } \\
\text { yang begitu gigih memperjuangkan nasib }\end{array}$ & \\
\hline
\end{tabular}




\begin{tabular}{|c|c|c|}
\hline & $\begin{array}{l}\text { bahasa Melayu hingga bahasa Melayu } \\
\text { berjaya menjadi wadah utama dalam semua } \\
\text { bidang. }\end{array}$ & \\
\hline AR1/H13/P1 & $\begin{array}{l}\text { Sultan al-Fatih yang berjaya menawan kota } \\
\text { Constantinopel pada usia } 21 \text { tahun, Usaman } \\
\text { bin Zalid yang berjaya mengetuai angkatan } \\
\text { tentera Islam ke wilayah Syam pada usia } 18 \\
\text { tahun, Imam Syafiee yang layak } \\
\text { mengeluarkan fatwa di Mekah pada usia } 15 \\
\text { tahun dan Imam al-Ghazali yang sudah } \\
\text { menjadi ilmuwan terkemuka pada usia } 20 \\
\text { tahun. }\end{array}$ & Sokongan \\
\hline AR1/H13/P1 & $\begin{array}{l}\text { Sultan al-Fatih yang berjaya menawan kota } \\
\text { Constantinopel pada usia } 21 \text { tahun, Usaman } \\
\text { bin Zalid yang berjaya mengetuai angkatan } \\
\text { tentera Islam ke wilayah Syam pada usia } 18 \\
\text { tahun, Imam Syafiee yang layak } \\
\text { mengeluarkan fatwa di Mekah pada usia } 15 \\
\text { tahun dan Imam al-Ghazali yang sudah } \\
\text { menjadi ilmuwan terkemuka pada usia } 20 \\
\text { tahun. }\end{array}$ & Kualiti \\
\hline AR1/H10/P1 & $\begin{array}{l}\text { 152. (1) Bahasa kebangsaan ialah bahasa } \\
\text { Melayu dan hendaklah dalam tulisan yang } \\
\text { diperuntukkan melalui undang-undang oleh } \\
\text { parlimen. }\end{array}$ & \\
\hline AR1/H11/P5 & $\begin{array}{l}\text { Api perjuangan marak menyala, walaupun } \\
\text { batang tubuh yang memperjuangkannya } \\
\text { sentiasa berubah. }\end{array}$ & Relevan \\
\hline $\begin{array}{l}\text { AR1/H10 } \\
\text { (Tajuk) }\end{array}$ & $\begin{array}{l}\text { Perjuangan Bahasa Melayu di Tangan Anak } \\
\text { Muda" }\end{array}$ & $\begin{array}{l}\text { Kepatuhan Pada } \\
\text { Tajuk }\end{array}$ \\
\hline AR1/H11/P3 & $\begin{array}{l}\text { Maka kita berpaling ke belakang untuk } \\
\text { melihat sejarah. }\end{array}$ & \multirow{3}{*}{ Penjagaan Air Muka } \\
\hline AR1/H12/P3 & $\begin{array}{l}\text { Dalam hal ini, adakah kita terfikir untuk } \\
\text { mendekati golongan muda? } \\
\text { Pernahkah diadakan program khusus untuk } \\
\text { orang muda mencurahkan buah fikiran } \\
\text { dalam isu berkaitan bahasa? }\end{array}$ & \\
\hline AR1/H11/P5 & $\begin{array}{l}\text { Melihat senario dan keadaan masyarakat } \\
\text { pada hari ini berkemungkinan kita perlu } \\
\text { berlembut lidah untuk memberikan } \\
\text { kesedaran kepada masyarakat tentang } \\
\text { kepentingan mengutamakan bahasa } \\
\text { kebangsaan. }\end{array}$ & \\
\hline
\end{tabular}


Maksim Kebijaksanaan dalam AR1 diperlihatkan menerusi cadangan penulis bagi menyampaikan hasrat murninya kepada khalayak pembaca. Dalam usaha memelihara aspek kesantunan berbahasa, pengarang banyak memberikan cadangan yang konstruktif kepada generasi muda agar berjuang memartabatkan bahasa Melayu. Cadangan tersebut terdapat dalam AR1/H12/P1. Cadangan ini memanifestasikan kredit dan kepercayaan yang diberikan oleh penulis kepada generasi muda dalam usaha menerajui perjuangan memartabatkan bahasa Melayu. Sementara itu, ayat dalam AR1/H13/P3 turut menggambarkan cadangan pengarang artikel ini kepada seluruh rakyat Malaysia agar bersama-sama menggunakan kesempatan ini untuk memajukan bahasa rasmi menerusi capaian teknologi. Pemilihan dan penggunaan kata ganti nama "kita" dalam cadangan ini mewakili rakyat Malaysia dan menunjukkan pengarang hendak menonjolkan sifat kebersamaan dan kemesraan dalam penulisannya supaya seluruh rakyat Malaysia merasai kebersamaan tersebut. Di samping itu, AR1-H13/P3 merupakan cadangan yang bernas di samping menyelitkan kepercayaan yang tidak berbelah bahagi daripada pengarang bagi menyedarkan golongan muda hari ini agar membuat persediaan yang rapi dari segi mental dan fizikal untuk memikul tanggungjawab memartabatkan bahasa Melayu. Cadangan-cadangan yang berupa peringatan mesra daripada pengarang kepada generasi muda sudah tentu dapat menjentik perasaan dan jiwa mereka untuk bertindak memartabatkan bahasa Melayu. Jika disorot, didapati cadangan-cadangan ini berupaya minimumkan kos generasi muda atau pembaca yang membaca artikel ini, iaitu khalayak tidak berasa terbeban sebaliknya mengambil iktibar daripada cadangan-cadangan tersebut untuk berjuang memartabatkan bahasa Melayu. Saranan dan cadangan ini juga disampaikan dengan cara yang sesuai selain berunsur pujukan. Perkara ini juga memperlihatkan kebijaksanaan pengarang melalui pemilihan dan penggunaan kata, frasa dan ayat yang bertepatan dan berkaitan dengan konteks perbincangan, iaitu memartabatkan bahasa kebangsaan. Kebijaksanaan dalam memberikan cadangan telah dikemukakan oleh Leech (1983) menerusi maksim kebijaksanaan, iaitu meminimumkan kos kepada orang lain, sebaliknya memaksimumkan lebih manfaat.

Maksim Kebijaksanaan turut diaplikasi menerusi penggunaan sapaan yang diperlihatkan menerusi pemilihan dan penggunaan kata sapaan yang sesuai dan tepat untuk mendekati orang lain. Penulis AR1 menzahirkan kepekaan dan kebijaksanaannya bagi menunjukkan sikap hormat dalam usaha menyantun tokohtokoh ternama seperti dalam AR1-H13/P1. Dalam artikel AR1, penggunaan kata panggilan hormat Imam untuk menggelar atau memanggil Imam Syafiee dan Imam al-Ghazali amat tepat dan santun bagi menandakan penghormatan terhadap keduadua tokoh yang telah memberikan sumbangan dan kejayaan yang besar dalam bidang agama Islam. Imam Syafiee merupakan ulama yang amalan mazhabnya menjadi pegangan sebahagaian umat Islam di dunia manakala Imam al-Ghazali pula merupakan tokoh pemikir Islam dan dianggap sebagai al-mujaddid yang juga wali Allah. Begitu juga dengan penggunaan kata sapaan rujukan kehormat untuk golongan istana, iaitu Sultan bagi menamakan Sultan Al-Fatih, amat sesuai dan bertepatan sekali dengan panggilan diraja bagi ketua yang memerintah sesebuah kerajaan. 
Pengarang juga menggunakan ungkapan sapaan hormat yang tepat, sesuai dan santun dalam membincangkan isu ini bagi mencerminkan kesantunan. Penggunaan ungkapan sapaan atau panggilan untuk golongan aktivis yang berjuang memartabatkan bahasa Melayu turut dikenal pasti dalam artikel AR1/H10/P12-13, iaitu pejuang bahasa, generasi pewaris, pelopor perjuangan, generasi terdahulu dan pencinta bahasa amat bersesuaian dan bertepatan dengan resolusi dan agenda perjuangan golongan ini sama ada yang terdahulu atau sekarang. Pejuang bahasa merujuk kepada mereka yang sanggup berkorban masa dan tenaga untuk mendaulatkan bahasa Melayu di bumi Malaysia manakala pencinta bahasa pula merujuk kepada mereka yang setia dan memiliki sifat sayang kepada bahasa kebangsaan. Generasi pewaris merujuk kepada golongan muda yang bakal menjadi pewaris atau pelapis pada masa hadapan manakala generasi terdahulu merujuk kepada golongan veteran yang pernah berjuang demi kedaulatan bahasa Melayu. Pelopor perjuangan pula merujuk kepada golongan pejuang yang menjadi perintis yang mendaulatkan bahasa Melayu. Penggunaan ungkapan-ungkapan sapaan tersebut memperlihatkan ciri-ciri yang relevan dengan inti pati perbincangan tentang penghargaan terhadap pejuang-pejuang bahasa yang memartabatkan bahasa Melayu. Pemilihan dan penggunaan ungkapan sapaan ini turut menzahirkan sikap kebijaksanaan penulis artikel AR1 demi mengukuhkan inti pati pendaulatan bahasa Melayu sebagaimana gagasan Leech (1983) dengan memaksimumkan manfaat kepada orang lain dan meminimumkan sebarang kos. Penulis artikel ini memperlihatkan kepekaan terhadap usaha untuk menghargai dan memberikan manfaat kepada pihak berkenaan melalui penggunaan ungkapan sapaan tersebut.

Pengarang juga mengaplikasikan maksim Kebijaksanaan menerusi selitan unsur nasihat dalam artikel ini menerusi AR1/H13/P4. Nasihat disampaikan penulis dengan penanda kata tugas perlu dalam ayat ini, iaitu rakyat Malaysia dinasihatkan agar mengenang jasa generasi terdahulu yang telah mendaulatkan bahasa Melayu. Kata tugas perlu ini turut bersinonim dengan berguna, berfaedah dan bermanfaat yang sesuai digunakan untuk memberikan nasihat (Kamus Dewan Edisi Keempat, 2007). Penulis tidak menggunakan perkataan "mesti" dan "harus" atau "wajib" dalam menitipkan nasihatnya agar khalayak pembaca tidak berasa terbeban sebaliknya memberikan ruang kepada pembaca untuk membuat penilaian. Penegasan penulis menerusi ungkapan perlu berterima kasih kepada generasi terdahulu amat signifikan untuk menasihat generasi masa ini agar tidak seperti kacang lupakan kulit. Nasihat yang disampaikan dengan cara yang baik dan sopan sudah tentu memaksimumkan manfaatkan kepada khalayak dan tidak memaksimumkan kos mereka sebagaimana gagasan Leech (1983) menerusi maksim Kebijaksanaan. Sarjana Indonesia, iaitu Hamka (2002, hlm. 50) menegaskan bahawa kesantunan meliputi kata-kata yang lemah lembut dan beradab mampu melembutkan hati seseorang.

AR1 turut memperlihatkan pengaplikasian maksim Sokongan dalam AR1H13/P1. Pengarang memuatkan pujian terhadap tokoh-tokoh berkenaan atas kehebatan dan kejayaan mereka menempah kegemilangan dalam usia yang masih muda dalam pelbagai bidang. Pengarang menandakan pujian menerusi kata kunci "berjaya" kepada kedua-dua tokoh yang telah menunjukkan kecemerlangan pada usia yang masih muda. Sementara itu, pujian terhadap Imam Syafiee ditandai kata 
kunci "layak", iaitu telah lulus atau diperakukan untuk mengeluarkan fatwa pada usia 15 tahun. Usia 15 tahun merupakan usia yang sangat muda tetapi tokoh ini telah melakar sejarah dan kejayaan yang besar. Pujian kepada Imam Ghazali pula ditandai frasa "ilmuan terkemuka" pada usia yang sangat muda, 20 tahun. IImuan terkemuka merujuk kepada cendekiawan atau cerdik pandai yang tersohor dan terkenal yang sukar untuk dicapai, tetapi mampu diraih Imam Ghazali pada usia muda. Pujian-pujian ini sewajarnya diberikan kepada tokoh-tokoh berkenaan atas jasa dan pencapaian mereka yang telah terlakar dalam sejarah. Pujian-pujian ini berkeupayaan untuk memberikan galakan dan dorongan kepada generasi muda agar menjadikan tokoh-tokoh ini sebagai teladan dalam mensinergikan perjuangan mereka memartabatkan bahasa rasmi negara. Abdul Mua'ti @Zamri Ahmad (2001, hlm. 37) menegaskan bahawa pujian yang ikhlas akan menjadi pendorong utama kepada pihak yang dipuji untuk meneruskan perbuatan baik dan merupakan petanda bahawa kita menghargai apa-apa yang mereka lakukan.

AR1 juga menunjukkan pengaplikasian maksim Kualiti yang diutarakan oleh Grice (1975). Berdasarkan ayat dan idea dalam AR1-H13/P1, pengarang memperlihatkan kekuatan dengan merujuk kepada sumber yang berkualiti, iaitu mengemukakan maklumat yang lengkap dan tepat tentang kejayaan tokoh-tokoh berkenaan. Misalnya, "Sultan al-Fatih yang berjaya menawan kota Constantinople pada usia 21 tahun", memperjelaskan bahawa tokoh ini terkenal di kota Constantinople, sebuah tempat yang ditawan oleh Sultan al-Fatih dan terpahat dalam sejarah Islam (Abdul Latip Talib, 2009, hlm. 70). Seterusnya, "Imam Syafiee yang layak mengeluarkan fatwa di Mekah" turut memperlihatkan penggunaan sumber yang sahih, iaitu tokoh imam yang benar-benar wujud dalam sejarah Islam dan terkenal di Mekah. Tindakan pengarang mengemukakan bukti atau fakta ini menunjukkan pengarang amat peka dan prihatin dengan sumber yang dirujuk bagi menghasilkan sebuah wacana yang berkualiti selain membuktikan wujudnya aspek koheren dan kohesi dalam penulisan. Perkara ini dapat dihubungkaitkan dengan maksim Kualiti yang dikemukakan Grice (1975), iaitu pengarang mengupas isu ini dengan mengutarakan contoh tokoh yang muktabar, berwibawa dan sememangnya wujud dalam sejarah Islam. Pembuktian ini menunjukkan bahawa wacana yang dihasilkan ini amat berkualiti atas faktor sumbernya tepat. Maksim Kualiti juga diperlihatkan dalam AR1-H10/P1. Penggunaan perkara 152 dalam perlembagaan merupakan bukti yang sahih dan kukuh bahawa bahasa Melayu telah diperuntukkan sebagai bahasa kebangsaan di Malaysia sebagaimana yang termaktub dalam Perlembagaan Malaysia. Pembuktian yang diberikan oleh penulis artikel ini menzahirkan kekuatan penulis dalam mengemukakan fakta yang sahih agar penulisannya berkualiti dan memenuhi tuntutan kesantunan.

Seterusnya, penggunaan maksim Relevan dalam Prinsip Kesantunan Grice diteliti menerusi AR1-H11/P5 "Api perjuangan marak menyala". Penggunaan ungkapan atau frasa yang indah atau puitis seperti api perjuangan, iaitu gaya bahasa metafora turut dipilih dan digunakan penulis bagi mencerminkan semangat perjuangan yang tinggi dan sewajarnya dimiliki rakyat Malaysia dalam usaha memartabatkan bahasa kebangsaan. Penggunaan ungkapan yang indah ini merupakan salah satu ciri kesantunan dalam bidang penulisan dan relevan dengan 
medan perbincangan dan agenda perdana dalam artikel ini, iaitu usaha menyemarakkan semangat untuk memartabatkan bahasa Melayu.

Artikel ini juga memperlihatkan penggunaan strategi kesantunan Asmah Haji Omar (1996) bukan hanya pengaplikasian maksim-makism Leech (1983) dan Grice (1975). Strategi kesantunan yang diaplikasi dalam artikel ini ialah kepatuhan pada tajuk atau bidang perbincangan atau perbahasan. Tajuk yang dikemukakan oleh pengarang amat bertepatan dengan inti pati yang dibicarakan secara tuntas dalam artikel ini. AR1/10 bertajuk "Perjuangan Bahasa Melayu di Tangan Anak Muda", amat mematuhi medan perbincangan dalam artikel ini yang memberikan fokus terhadap saranan dan cadangan terhadap usaha yang wajar diambil generasi muda untuk mendaulatkan bahasa Melayu. Fokus perbincangan turut membicarakan usaha-usaha pejuang bahasa terdahulu dalam memartabatkan bahasa kebangsaan ini. Pengarang memulakan wacana dengan mengetengahkan perkara 152 dalam perlembagaan Malaysia yang memperuntukkan keistimewaan bahasa Melayu sebagai bahasa kebangsaan. Seterusnya, pengarang menelusuri sejarah perjuangan bahasa Melayu dalam menempatkan dirinya sebagai bahasa yang utuh, sejak dari zaman sebelum merdeka sehinggalah negara mengecapi kemerdekan. Seterusnya, pengarang membicarakan fungsi dan peranan penting golongan muda dalam memartabatkan bahasa Melayu. Perbincangan dan kupasan yang bertepatan dengan tajuk artikel, membuktikan bahawa penulis mematuhi tatacara penulisan. Hal ini ditambah pula wacana ini memiliki kesatuan yang lengkap organisasi maklumatnya dari pengenalan, isi kandungan sehinggalah kepada penutupnya. Pematuhan terhadap tajuk perbincangan amat penting bagi memastikan artikel berkenaan memiliki kesantunan atau sebaliknya. Asmah Omar (1996) memberikan penegasan bahawa kepatuhan kepada tajuk atau bidang perbincangan atau perbahasan merupakan salah satu ciri kesopanan dalam peristiwa bahasa.

Penulis artikel ini juga mementingkan strategi penjagaan air muka sebagaimana yang diketengahkan oleh Asmah Omar (1996). Penjagaan air muka dilakukan bagi mengelakkan sesuatu pihak berasa tersinggung atau berkecil hati. Pengarang tidak menyalahkan atau mengutuk golongan muda sebaliknya memberikan cadangan agar golongan muda berjuang memartabatkan bahasa Melayu. Pengarang menggunakan ungkapan dan ayat yang mencerminkan penjagaan air muka seperti dalam AR1-H11/P3 ketika mengetengahkan bahawa situasi bahasa Melayu masih terumbang-ambing atau tidak stabil dengan mengingatkan semua rakyat Malaysia agar menoleh dan mengkaji sejarah kegemilangan bahasa Melayu pada abad ke-19 dalam usaha memartabatkan bahasa Melayu. Ayat ini menggambarkan bahawa penulis memohon agar masyarakat tidak melupakan sejarah silam dalam mendepani kemelut yang meracuni bahasa kebangsaan pada hari ini. Penulis sangat menjaga sensitiviti sehingga tidak ditemukan ungkapan-ungkapan yang menyinggung mana-mana pihak sebaliknya, menggunakan ayat secara berlapik dalam usaha memberikan pengajaran kepada khalayak pembaca.

Dalam mewujudkan kesantunan berbahasa menerusi penjagaan air muka pengarang turut menggunakan strategi pertanyaan. Pertanyaan yang dilontarkan oleh pengarang dalam artikel ini dapat memugar proses berfikir dan tidak menunjukkan unsur paksaan. Misalnya dalam AR1-H12/P3 "adakah kita terfikir 
untuk mendekati golongan muda?" dan dalam ayat "Pernahkah diadakan program khusus untuk orang muda mencurahkan buah fikiran dalam isu berkaitan bahasa?". Walaupun pertanyaan berfungsi bagi mendapatkan ketepatan maklumat namun dalam konteks artikel ini, pertanyaan berfungsi untuk menegaskan kepentingan isu memartabatkan bahasa Melayu oleh generasi muda. Pengarang membuat penegasan terhadap usaha untuk mendekati golongan muda dan program khusus untuk orang muda mencurahkan buah fikiran. Kedua-dua maklumat ini amat signifkan jika kita berhasrat untuk melihat generasi muda menjadi lebih proaktif dan progresif memainkan peranan mereka. Oleh itu, pengarang menggunakan strategi pertanyaan bagi menjadikan penulisannya lebih berkesan selain memugar daya fikir khalayak pembaca. Tersiratnya, pengarang sebenarnya membuat permintaan terhadap khalayak pembaca atau pihak-pihak yang berkepentingan agar isu ini dapat diatasi dan generasi muda dapat bersiap siaga memainkan peranan mereka. Hal ini bertepatan dengan pandangan Siti Hajar Abdul Aziz (2009, hlm. 97) yang mengaitkannya dengan kesopanan, iaitu salah satu cara untuk menjadikan permintaan nampak lebih sopan dan beradab adalah dengan menggunakan permintaan dalam bentuk pertanyaan. Dalam konteks analisis ini, penggunaan strategi pertanyaan ini turut memberikan ruang keselesaan dan kebebasan kepada golongan yang menjadi fokus perbincangan, iaitu generasi muda agar tidak menanggung kos atau terbeban. Sara Beden (2018, hlm. 58) turut menegaskan bahawa strategi pertanyaan memudahkan pembaca memahami dan memproses maklumat yang dihasratkan pengarang sekali gus menjadikan idea yang disampaikan jelas dan ringkas. Impaknya, penulisan AR1 ini menarik dan tidak memperlihatkan unsur paksaan.

Strategi penjagaan air muka turut terdapat dalam AR1-H11/P5. Ungkapan "berlembut lidah" dalam ayat tersebut merupakan ungkapan santun yang halus dan lembut dalam berbahasa yang membawa maksud bersuara lunak, merdu dan perlahan dalam usaha menyedarkan masyarakat tentang kepentingan mengutamakan bahasa kebangsaan. Penggunaan frasa berlembut lidah ini amat bertepatan dengan usaha memberi kesedaran kepada masyarakat dengan cara yang lebih lembut dan tidak agresif. Dalam usaha memberikan kesedaran, segala idea dan saranan wajar disampaikan dengan lembut dan beralas agar mudah dihadam dan diterima masyarakat. Berdasarkan ungkapan ini, ternyata penulis artikel ini amat menjaga air muka pembaca dengan membuat saranan secara berlapik agar tidak ada pihak yang sensitif dengan saranan tersebut.

\section{Perjuangan yang Masih Berliku (AR2)}

Seterusnya, berdasarkan analisis terhadap AR2 pula, didapati AR2 mematuhi maksim Kebijaksanaan + Sokongan + Kualiti + Cara + Kepatuhan pada Tajuk + Penjagaan Air Muka sebagaimana dalam Jadual 6 berikut. 
Jadual 6

Pola kombinasi maksim Kebijaksanaan + Sokongan + Kualiti + Cara + Kepatuhan pada Tajuk + Penjagaan Air Muka

\begin{tabular}{|c|c|c|}
\hline AR2/halaman & Artikel & $\begin{array}{l}\text { Pola Pola kombinasi } \\
\text { maksim + strategi }\end{array}$ \\
\hline AR2-H6/P1 & $\begin{array}{l}\text { Campur tangan kesultanan Malaysia seperti titah } \\
\text { Sultan Nazrin Muizzuddin Shah dalam usaha } \\
\text { memartabatkan bahasa Melayu ... }\end{array}$ & \multirow{4}{*}{ Kebijaksanaan } \\
\hline AR2-H8/P3 & $\begin{array}{l}\text { Profesor Datin Paduka Datuk Dr. Ramlah Adam } \\
\text { dalam kajiannya yang bertajuk ... }\end{array}$ & \\
\hline & $\begin{array}{l}\text {... apabila Perdana Menteri Tun Dr. Mahathir } \\
\text { Mohamad membuat pengumuman bahawa ... }\end{array}$ & \\
\hline AR2-H9/P2 & $\begin{array}{l}\text { Namun nada berbeza ... Felo Utana Institut } \\
\text { Kajian Etnik, UKM Prof. Datuk Dr. Teo Kok Seong } \\
\text {... }\end{array}$ & \\
\hline AR2-H8/P3 & $\begin{array}{l}\text { Hal ini membuktikan komitmen dan } \\
\text { kesungguhan kerajaan untuk menjadikan } \\
\text { bahasa Melayu sebagai bahasa ilmu yang tinggi } \\
\text { tarafnya. }\end{array}$ & \multirow[t]{2}{*}{ Sokongan } \\
\hline AR2-H9/P3 & $\begin{array}{l}\text { Bahasa Melayu yang paling layak dimartabatkan } \\
\text { sebagai bahasa ilmu dalam setiap lapisan } \\
\text { pendidikan negara kita berbanding dengan } \\
\text { bahasa-bahasa lain di dunia. }\end{array}$ & \\
\hline AR2-H7/P1 & $\begin{array}{l}\text { Perjuangan memartabatkan bahasa Melayu } \\
\text { sebagai bahasa kebangsaan dibangkitkan oleh } \\
\text { raja-raja Melayu dalam mesyuarat Durbar pada } \\
\text { tahun } 1903 \text {... }\end{array}$ & \multirow{4}{*}{ Kualiti } \\
\hline & $\begin{array}{l}\text {..Perlembagaan Persekutuan Tanah Melayu pada } \\
5 \text { Ogos } 1957 .\end{array}$ & \\
\hline AR2-H8/P1 & $\begin{array}{l}\text { Akta Bahasa Kebangsaan 1963/1967- Akta } 32 \\
\text { Kemas kini } 2006 \text { pula menetapkan bahawa } \\
\text { "Bahasa Kebangsaan (bahasa Melayu) hendaklah } \\
\text { digunakan bagi maksud rasmi". }\end{array}$ & \\
\hline AR2-H8/P2 & $\begin{array}{l}\text {... Barisan Bertindak Bahasa Kebangsaan dan } \\
\text { berjaya menghimpunkan seramai } 2000 \\
\text { nasionalis pada } 3 \text { Mac 1967. Peristiwa tersebut } \\
\text { dirujuk sebagai "Keranda 152". }\end{array}$ & \\
\hline AR2-H9/P1 & $\begin{array}{l}\text { Antaranya, termasuklah masalah guru yang tidak } \\
\text { dapat menyampaikan ilmu tersebut dengan } \\
\text { berkesan disebabkan guru terbabit tidak mahir } \\
\text { bertutur dalam bahasa Inggeris sehinggakan } \\
\text { kebanyakan guru menggunakan campuran }\end{array}$ & \\
\hline
\end{tabular}




\begin{tabular}{|c|c|c|}
\hline & $\begin{array}{l}\text { bahasa Inggeris dan bahasa Melayu dalam PdP } \\
\text { mreka seperti yang terdapat dalam laporan } \\
\text { "Kajian Kompetensi Guru dalam PPISMI serta } \\
\text { implikasinya terhadap Prestasi ke Arah Modal } \\
\text { Insan". }\end{array}$ & Cara \\
\hline AR2-H6 & Tajuk: “Perjuangan yang Masih Berliku” & $\begin{array}{c}\text { Kepatuhan Pada } \\
\text { Tajuk }\end{array}$ \\
\hline AR2-H8/P3 & $\begin{array}{l}\text { Namun, perjalanan bahasa Melayu sebagai } \\
\text { bahasa kebangsaan terutama bahasa ilmu } \\
\text { disangka panas hingga ke petang rupanya hujan } \\
\text { di tengah hari apabila kembali dihimpit isu-isu } \\
\text { panas pada thun } 1990 \text {-an. }\end{array}$ & \\
\hline AR2-H9/P2 & $\begin{array}{l}\text { Walau apa pun sebab dan alasan yang diberikan, } \\
\text { pelaksanaan DLP ibarat luka lama berdarah } \\
\text { kembali kepada semua pihak yang } \\
\text { memperjuangkan pemansuhan PPSMI }\end{array}$ & Penjagaan Air Muka \\
\hline AR2-H9/P2 & $\begin{array}{l}\text { Perjalanan bahasa Melayu sebagai bahasa } \\
\text { kebangsaan masih berliku biar pun PPSMI telah } \\
\text { dimansuhkan. }\end{array}$ & \\
\hline AR2-H9/P3 & $\begin{array}{l}\text { Berdasarkan pemerhatian, perjalanan bahasa } \\
\text { Melayu terutamanya sebagai bahasa ilmu penuh } \\
\text { dengan onak duri. }\end{array}$ & \\
\hline AR2-H8/P4 & $\begin{array}{l}\text { Tindakan kerajaan untuk kembali menjadikan } \\
\text { bahasa lain sebagai bahasa pengantar melalui } \\
\text { Dasar Pengajaran S dan M dalam BI (PPSMI) } \\
\text { pada tahun } 2003 \text { dilihat cuba mengurangkan } \\
\text { fungsi bahasa Melayu sebagai bahasa ilmu } \\
\text { seperti yang ditetapkan oleh Perlembagaan } \\
\text { Persekutuan, Akta Bahasa Kebangsaan, Akta } \\
\text { Pendidikan dan Akta Dewan Bahasa Dan } \\
\text { Pustaka. }\end{array}$ & \\
\hline
\end{tabular}

Maksim Kebijaksanaan dalam AR2 diperlihatkan menerusi ketepatan penggunaan sapaan rujukan kehormat kepada golongan istana dalam ayat AR2H6/P1. Pemerintah Kerajaan Perak, digelar Sultan yang menandakan sapaan rujukan kehormat bagi golongan diraja. Penzahiran penggunaan kata sapaan rujukan kehormat untuk golongan berkenaan menandakan aspek kesantunan yang tinggi. Penulis menunjukkan kepekaan dengan tidak mengabaikan aspek ini dalam penulisan.

Sehubungan itu, dalam AR2 terdapat juga sapaan hormat terhadap golongan yang diberi gelaran kurniaan dan anugerah akademik atas pencapaian akademik tertinggi dan atas jasa atau sumbangan mereka kepada negara. Dalam AR2 -H8/P3 "Profesor Datin Paduka Datuk Dr. Ramlah Adam dalam kajiannya yang bertajuk ...", 
memperlihatkan kepekaan penulis untuk menamakan tokoh ini dengan meletakkan anugerah akademik, gelaran kurniaan kerajaan dan kelayakan akademik tertinggi di Malaysia kepada beliau, iaitu "Profesor + Datin Paduka Datuk + Dr" Begitu juga dalam AR2-H9/P2, ayat "Namun nada berbeza ... Felo Utama Institut Kajian Etnik, UKM Prof. Datuk Dr. Teo Kok Seong ...". Dr. Teo Kok Seong turut dinamakan dengan betul anugerah akademik, gelaran kurniannya oleh kerajaan dan kelayakan akademik tertinggi di Malaysia, iaitu "Profesor + Datuk + Dr" Perkara ini juga terdapat dalam AR2-H8/3 berdasarkan ayat "... apabila Perdana Menteri Tun Dr. Mahathir Mohamad membuat pengumuman bahawa ...". Penulis tidak mengabaikan tatacara kesantunan penulisan dengan menamakan jawatan dan gelaran kurniaan kepada Perdana Menteri "Tun Dr. Mahathir Mohamad". Gelaran "Tun" yang merupakan gelaran kurniaan tertinggi di Malaysia telah dikurniakan kepada beliau oleh di-Pertuan Agong atas jasa dan sumbangannya kepada kerajaan dan rakyat manakala Dr (bidang perubatan) merupakan profesion beliau sebelum melibatkan diri dalam bidang pentadbiran. Ketepatan dan kesesuaian penggunaan sapaan hormat ini menandakan pengarang seorang yang peka dan bijaksana dalam memastikan kesantunan penulisannya terpelihara.

Perbincangan penulis dalam AR2 turut mengaplikasikan maksim Sokongan dalam PS Leech (1983). Hal ini memanifestasikan bahawa pengarang tidak meminggirkan unsur pujian dalam penghasilan artikelnya. Strategi pujian diaplikasikan dalam AR2-H8/P3. Pujian diberikan kepada pihak kerajaan menerusi kata kunci "komitmen" dan "kesungguhan" dalam mendaulatkan bahasa Melayu. Hal ini menunjukkan penulis peka akan peranan dan inisiatif yang diambil kerajaan dalam meninggikan martabat bahasa Melayu walaupun banyak halangannya. Seterusnya, AR2-H9/P3 turut mencitrakan pujian kepada bahasa Melayu apabila penulis menggunakan frasa "paling layak" dalam menandai pujiannya. Kata penguat paling merujuk kepada darjah sangat tinggi dan layak pula diperakukan sah. Oleh itu, pujian ini amat menyenangkan hati pembaca khususnya pencinta dan pejuang bahasa. Strategi pujian yang diaplikasikan penulis AR2 ini bertepatan dengan gagasan Leech yang telah mengetengahkan maksim Sokongan dengan menggagaskan bahawa kita sewajarnya memaksimumkan pujian bagi menyenangkan hati pihak lain sama ada dalam komunikasi bertulis mahupun lisan. Berdasarkan Leech (1983), tiada pihak yang tidak menyukai pujian.

Pengaplikasian Prinsip Kerjasam Grice (1975) menerusi maksim Kualiti terdapat dalam AR2-H7/1. Penggunaan fakta yang sahih dan benar menerusi "mesyuarat Durbar pada tahun 1903" membuktikan bahawa pihak raja-raja Melayu telah berusaha memartabatkan bahasa Melayu pada masa itu. Sementara penggunaan "...Perlembagaan Persekutuan Tanah Melayu pada 5 Ogos 1957". Penggunaan fakta-fakta sejarah membuktikan ketelitian penulis artikel AR2 dalam penghasilan penulisan yang berkualiti sebagaimana gagasan Grice (1975). Seterusnya, bagi mengukuhkan fakta dalam penulisan, penulis menggunakan Akta Bahasa kebangsaan 1963/1967 menerusi ayat AR2-H8/P3. Akta ini menguatkan bukti perjuangan dan usaha pihak-pihak berkenaan dalam memastikan kedaulatan bahasa Melayu terpelihara. Begitu juga dengan penggunaan ayat AR2-H8/P3. Penggunaan fakta ini berupaya menyedarkan masyarakat tentang sejarah suram bahasa Melayu sehingga membawa kepada perhimpunan 3 Mac 1967. Penggunaan fakta yang 
tepat sebagai sumber rujukan dan bukti dalam penulisan menjadikan sesebuah penulisan tersebut berkualiti sekali gus menggambarkan penulis tidak hanya bersembang kosong. Perjuangan, pelaksanaan, peristiwa dan tindakan-tindakan pihak tertentu dalam usaha memartabatkan bahasa Melayu dibuktikan dengan sahih menerusi akta dan peristiwa dengan tarikh yang tepat.

Berdasarkan strategi kesantunan Asmah Haji Omar, didapati penulis artikel ini menggunakan strategi Kepatuhan pada Tajuk. AR2 bertajuk "Perjuangan yang Masih Berliku". Isi kandungan artikel bermula dengan pengenalan, isi dan penutup yang mematuhi kehendak dan inti pati tajuk artikel. Bahagian pengenalan mengupas tentang kegoyahan dan nasib bahasa Melayu yang terumbang-ambing diancam isuisu panas. Isi-isi atau inti pati AR2 pula membicarakan sejarah, akta-akta berkaitan dan program-program atau agenda pihak-pihak berkepentingan terhadap bahasa Melayu sehingga fungsi bahasa Melayu terjejas. Penutup AR2 pula menyimpulkan bahawa bahasa Melayu sewajarnya diangkat dan selayaknya menjadi bahasa ilmu selain menyeru agar semua lapisan masyarakat bersama-sama memartabatkan bahasa Melayu. Keseluruhan perbincangan dalam artikel ini mematuhi ruang lingkup tajuk AR2 sebagaimana gagasan Asmah Omar menerusi strategi Kepatuhan pada tajuk. Kepatuhan pada tajuk amat penting dalam memastikan sesuatu penulisan tersebut berkualiti atau sebaliknya kerana ketidakpatuhan pada tajuk perbincangan menyebabkan hasil penulisan menyeleweng dan keluar dari tajuk, sekali gus mencerminkan pengabaian dan kepincangan terhadap kesantunan penulisan.

Penulisan AR2 juga memberi penekanan terhadap strategi penjagaan air muka yang melibatkan maruah. Strategi ini diaplikasi dalam AR2-H8 menerusi ayat "Namun, perjalanan bahasa Melayu sebagai bahasa kebangsaan terutama bahasa ilmu disangka panas hingga ke petang rupanya hujan di tengah hari apabila kembali dihimpit isu-isu panas pada tahun 1990-an". Penggunaan peribahasa disangka panas hingga ke petang rupanya hujan di tengah hari, mencerminkan strategi yang digunakan oleh penulis untuk menggunakan unsur bahasa kiasan atau figuratif agar agenda yang dikemukakan lebih berlapik untuk menggambarkan kemelut dan polemik yang mengancam bahasa Melayu sebagai bahasa kebangsaan pada tahun 1990-an. Harapan dan impian menggunung para pejuang bahasa terkandas di tengah jalan apabila pihak berkepentingan melaksanakan dasar-dasar yang mengakibatkan ancaman kepada kedudukan bahasa Melayu sebagai bahasa kebangsaan. Penggunaan peribahasa ini menggambarkan penulis amat mementingkan kehalusan dalam mengungkapkan buah fikiran agar tidak menyinggung perasaan mana-mana pihak.

Selain itu, strategi penjagaan air muka juga terdapat dalam AR2-H9. Dalam ayat ini terdapat penggunaan perumpamaan, iaitu "ibarat luka lama berdarah kembali" bagi menzahirkan perasaan kecewa dan terkilan pihak pejuang bahasa apabila dual-language program (DLP) dilaksanakan bagi menggantikan PPSMI. Kekecewaan pejuang bahasa berulang kembali sebagaimana pada zaman PPSMI diperkenalkan dahulu namun diutarakan secara berlapik oleh penulis menerusi kias ibarat agar dapat menjaga perasaan semua pihak. Pencinta dan pejuang bahasa sudah tentu berasa kecewa dan terluka dengan perlaksanaan DLP yang bakal menggugat martabat bahasa rasmi. Penulis memiliki objektif untuk menjaga sensitiviti semua pihak menerusi penggunaan bahasa figuratif. 
Sementara penggunaan ungkapan masih "berliku" dalam AR2-H9/P3 menandakan penggunaan bahasa beralas bagi mencitrakan ranjau perjalanan yang dilalui pejuang-pejuang bahasa dalam memartabatkan bahasa Melayu. Begitu juga dalam ayat "Berdasarkan pemerhatian, perjalanan bahasa Melayu terutamanya sebagai bahasa ilmu penuh dengan onak duri", turut memperlihatkan frasa atau ungkapan yang berlapik, iaitu "penuh dengan onak duri" bagi menzahirkan gelora, kendala-kendala dan pahit maung yang dihadapi bahasa Melayu dalam meniti perjalanan sebagai bahasa kebangsaan. Penulis AR2 menggunakan ungkapanungkapan ini sebagai asosiasi tidak berterus terang untuk mengekpresikan perasaan dan pandangan beliau tentang konflik dan nasib malang yang menimpa bahasa Melayu.

Pengaplikasian strategi Penjagaan Air Muka ini turut terdapat dalam AR2H8/P1. Berdasarkan ayat tersebut, penulis menggunakan ungkapan "dilihat cuba mengurangkan fungsi bahasa Melayu" merupakan ungkapan yang berlapik kerana tidak secara terang-terangan atau secara tidak langsung menzahirkan bahawa peranan bahasa Melayu sebagai bahasa ilmu disempitkan dan terjejas setelah pelaksanaan PPSMI. Oleh itu, penulis menggunakan ungkapan "cuba mengurangkan" dalam memperlihatkan tindakan pihak-pihak tertentu yang memperkecil dan memperlekeh peranan bahasa Melayu sebagai bahasa ilmu untuk menjaga hati semua pihak. Perkataan cuba dalam konteks ayat ini bermaksud sekiranya atau seandainya atau tidak ada ketetapan yang mutlak (Kamus Dewan Edisi Keempat, 2007) sebagai gambaran kehalusan bicara penulis agar berupaya menjaga air muka pihak-pihak berkepentingan atas tindakan mereka yang memperkecil kebolehan bahasa Melayu sekali gus menyantuni khalayak pembaca.

Stategi Penjagaan Air Muka yang digunakan penulis berupaya mengurangkan ketegangan pembaca apabila penulis membangkitkan polemik, ranjau dan liku-liku yang dihadapi bahasa Melayu sejak dari dahulu sehingga kini untuk menjadi bahasa kebangsaan yang mantap dan disegani dengan cara yang halus. Jeniri Amir (2009, hlm. 51) menegaskan bahawa penggunaan bahasa yang halus dan bersopan akan memberikan kesan yang besar terhadap minda khalayaknya, iaitu pendengar (pembaca) akan berasa tenteram dan bahagia. Jika sebaliknya, akan menyebabkan perasaan sesuatu pihak terhiris dan tersinggung. Pandangan ini bertepatan dengan tatacara penulis mengetengahkan isu pemartabatan bahasa Melayu dengan cara yang berhemah, halus dan santun kerana isu ini boleh menjadi isu panas dan membangkitkan sensitiviti pihak-pihak berkepentingan sekali gus mengecewakan para pejuang bahasa.

\section{Kesimpulan}

Berdasarkan analisis, didapati kedua-dua artikel yang menjadi data korpus ini sarat dengan aspek kesantunan berbahasa yang diperlihatkan menerusi pembentukan pola kombinasi maksim + strategi. AR1 memperlihatkan pematuhan terhadap maksim Kebijaksanaan + Sokongan + Kualiti + Relevan + Kepatuhan pada Tajuk + Penjagaan Air Muka manakala AR2 pula mematuhi maksim Kebijaksanaan + Sokongan + Kualiti + Cara + Kepatuhan pada Tajuk + Penjagaan Air Muka. Hasil analisis terhadap data dalam kedua-dua artikel menunjukkan pengaplikasian maksim 
yang sama cuma perbezaannya kewujudan maksim Relevan dalam AR1 manakala maksim Cara dalam AR2. Perkara ini berlaku atas faktor setiap artikel yang ditulis mempunyai objektif yang tersendiri untuk menyantuni khalayak pembaca walaupun kedua-dua artikel diletakkan dalam ruangan yang sama. Impaknya, pengaplikasian maksim bagi setiap artikel menunjukkan perbezaan bagi memenuhi tuntutan objektif penyampaian maklumat. Pengaplikasian strategi kesantunan Asmah Haji Omar pula memperlihatkan persamaan, iaitu pengaplikasian strategi Kepatuhan pada Tajuk dan strategi Penjagaan Air Muka. Situasi ini memperlihatkan bahawa setiap penulisan sewajarnya mematuhi tajuk agar maklumat tidak menyeleweng daripada landasan sebenar. Penulis juga memperlihatkan sikap berhati-hati dengan mengutamakan strategi penjagaan air muka agar tidak menimbulkan sebarang konflik mahupun mencalar maruah mana-mana pihak.

Pematuhan kedua-dua artikel dengan mengaplikasikan maksim kebijaksanaan menunjukkan bahawa penulis berusaha untuk memberikan manfaat dan meminimumkan kos pembaca apabila maklumat yang disampaikan tidak membebankan khalayak pembaca. Maksim Kebijaksanaan didapati wujud dalam semua pola kombinasi maksim + strategi yang terbentuk. Penggunaan maksim kebijaksanaan memberikan gambaran bahawa aspek kesopanan berhubung rapat dengan kearifan seseorang dalam bidang penulisan agar mesej disampaikan dengan cara yang berhemah. Tenas Effendy (2010, hlm. 24) mengungkapkan tunjuk ajar dalam budaya Melayu yang berbunyi "Apa tanda orang yang bijak, berfikir dahulu sebelum bertindak, Apa tanda orang beradab, berfikir dahulu sebelum mengungkap". Ungkapan ini menjelaskan bahawa budaya Melayu bukan sahaja memberikan penegasan agar berfikir sebelum melakukan sesuatu pekerjaan malahan kita diseru agar berfikir terlebih dahulu sebelum mengujarkan kata-kata. Maksim Kebijaksanaan ditandai menerusi ungkapan mencadang, menasihat, penggunaan kata sapaan hormat dan ganti nama yang betul dan tepat. Penggunaan kata sapaan hormat dan ganti nama yang betul dan tepat mencitrakan kehalusan berbahasa yang menjadi lambang jati diri ketamadunan bangsa Melayu. Cadangan dan nasihat pula bersifat negatif. Walau bagaimanapun, jika disampaikan secara berhemah dengan pemilihan kata yang sesuai, halus dan lembut atau tidak memaksa maka dapat memantulkan citra kesantunan berbahasa. Menurut Tenas Effendy (2011, hIm. 40), orang tua-tua ada mengatakan "Apabila hendak memberi saran, elokkan niat luaskan fikiran". Pendapat ini merupakan suatu representasi bahawa pemikiran yang bernas dan niat yang ikhlas amat penting agar saranan memberikan manfaat kepada orang lain sebagaimana tindakan kedua-dua penulis dalam artikel yang dikaji.

Maksim Sokongan ditandai kata sifat yang positif, iaitu pujian kepada orang lain selain memberikan penghargaan atas jasa dan kesejahteraan seseorang. Tindakan ini dapat memaksimumkan pujian dan meminimumkan cacian terhadap orang lain sama ada dalam komunikasi bertulis mahupun lisan. Pujian perlu dalam kasus tertentu kerana ketiadaan pujian mengimplikasikan cacian (Leech, 1993). Unsur pujian dalam analisis ini diperlihatkan menerusi pujian terhadap tokoh-tokoh Islam bagi mencerminkan sokongan dan kekaguman penulis dengan sumbangan mereka sama ada dari segi ilmu pengetahuan mahupun kepakaran dan kemahiran. 
Sementara itu, kehadiran Maksim Kualiti pula memperlihatkan keperluan pemberian maklumat yang benar atau sahih agar mesej menjadi efektif dan diyakini pembaca. Penggunaan maksim ini amat signifikan dalam analisis terhadap keduadua artikel dan memanifestasikan kepentingan nilai kejujuran sekali gus dapat meningkatkan kepercayaan pembaca. Abdullah Hassan dan Ainon Ahmad, (1999, $\mathrm{hlm}$.15) menyatakan bahawa maklumat yang disampaikan dengan tepat dan tidak palsu atau mempunyai fakta perlu diberi keutamaan kerana berkaitan dengan etika. Penggunaan akta, peristiwa-peristiwa bersejarah dengan tahun kejadiannya dan nama-nama tokoh yang wujud secara realiti dalam data korpus ini memperlihatkan bahawa penulis sangat menitikberatkan kualiti penulisannya selain memaparkan bukti yang kukuh.

Maksim Relevan pula memaparkan pemberian maklumat yang mempunyai pertalian dan ciri-ciri yang rapat dengan sesuatu maklumat yang diekspresikan penulis. Penggunaan maksim ini dapat melancarkan pemberian maklumat yang berkaitan dengan sesuatu perkara yang menjadi topik perbincangan. Maksim Cara pula menzahirkan pemberian maklumat yang terperinci, tersusun dan padat agar mudah difahami dan jelas. Kehadiran maksim ini memudahkan pembaca memproses, memahami dan menerima atau menghadam sebarang mesej atau maklumat yang dibaca.

Pematuhan kedua-dua data korpus terhadap strategi kepatuhan kepada tajuk menunjukkan kedua-dua penulis amat peka dan prihatin dengan tugas sebagai penulis. Penulis bertanggungjawab menyajikan wadah yang bersesuaian dan relevan dengan tajuk perbincangan. Selain itu, pengaplikasian strategi penjagaan air muka dipaparkan menerusi strategi pertanyaan, peribahasa, perumpamaan dan ungkapan yang berlapik dalam usaha penulis artikel menyantuni pembaca. Penggunaan bahasa figuratif dalam penulisan kedua-dua artikel membuktikan bahawa bidang komunikasi bertulis mementingkan keindahan, kehalusan dan ketinggian pemikiran dalam menzahirkan daya keintelektualan penulis. Penggunaan bahasa ini turut berperanan sebagai penyokong hujah dan pernyataan penulis agar mesej yang disampaikan kepada khalayak lebih efektif selain memperlihatkan sikap berhati-hati penulis dalam menyampaikan maklumat. Noriati A. Rashid (2005, hlm. 235), menyatakan bahawa orang Melayu sangat mementingkan perasaan orang lain dan ini menjadi pertimbangan dan pengukur dalam membuat keputusan. Pandangan ini memanifestasikan bahawa setiap ahli masyarakat sewajarnya mementingkan perilaku yang santun dengan membuat pemilihan kata dan ungkapan yang tepat dan sesuai agar dapat menjaga air muka dan tidak menyinggung perasaan mana-mana pihak.

Kesopanan berbahasa amat signifikan untuk dibudayakan dalam kehidupan masyarakat keseluruhannya sama ada dalam komunikasi lisan atau bertulis. Mohd Fahmi Mohamed Zaki (2011, hlm. 14) menegaskan bahawa dengan bahasa kita menyembunyikan atau mengungkapkan fikiran dan dengan bahasa juga kita dapat mengakhiri sesuatu konflik dan pertelingkahan. Sementara Azlina Mohd Kiram (2010, hlm. 61) berpendapat bahawa Islam juga menegaskan umatnya supaya sentiasa memelihara aib diri dan orang lain, menjaga kesopanan tutur kata dan tingkah laku serta memelihara maruah kerana Allah. Tegasnya, kedua-dua pandangan tersebut, memperjelas bahawa bahasa yang sopan sama ada melalui 
saluran lisan mahupun bertulis berkeupayaan melahirkan bangsa yang bertamadun, berjati diri, memiliki sahsiah terpuji dan terhindar daripada sengketa.

Tuntasnya, kejelasan dan perincian aspek kesantunan penulisan dalam data korpus kajian memperlihatkan sejelasnya agenda besar dan signifikan Dewan Bahasa dan Pustaka dalam usaha memartabatkan bahasa Melayu agar terus mengakar ke bumi, menjulang ke langit. Ruangan agenda bahasa, bicara bahasa, reaksi bahasa, bahasa dan pemikiran, dan penyelidikan bahasa bukan sahaja memberikan manfaat yang maksimum kepada khalayak bahasa malahan memperlihatkan aspek kesantunan berbahasa khususnya dalam bidang penulisan. Sewajarnya generasi muda sejak dari zaman persekolahan dididik menggunakan bahasa yang betul dan mendalami jati diri dan budaya berbahasa sama ada dalam bentuk lisan mahupun tulisan. Arina Johari, Nurul Jamilah Rosly, Sara Beden, dan Norlela Abdollah (2018, hlm. 108) menegaskan bahawa aspek pengajaran dan pembelajaran bahasa tidak seharusnya hanya berfokuskan mekanisme bahasa, sebaliknya menerapkan nilai budaya pragmatik yang berupaya mendedahkan tataadab komunikasi. Ringkasnya, bidang penulisan kekal signifikan sebagai medium untuk penyebaran maklumat namun aspek kesantunannya tidak boleh dianaktirikan oleh semua pihak khususnya yang mencintai bahasa kebangsaan.

\section{Rujukan}

Abdul Latip Talib. (2009). Sultan Muhammad Al-Fateh. Selangor, Malaysia: PTS Professional Publishing Sdn. Bhd.

Abdullah Hassan \& Ainon Ahmad. (1999). Komunikasi untuk guru. Kuala Lumpur, Malaysia: Utusan Publications \& Distributors Sdn. Bhd.

Abdullah Hassan. (2006). Sintaksis Siri Pengajaran dan pembelajaran bahasa Melayu. Kuala Lumpur, Malaysia: PTS Professional Publishing Sdn. Bhd.

Abdul Malik Karim Amrullah (2002). Merantau ke Deli. Kuala Lumpur, Malaysiar: Crescent News.

Abdul Mua'ti @ Zamri Ahmad. (2001).Santun komunikasi. Kuala Lumpur, Malaysia: Dewan Bahasa dan Pustaka.

Amirah Syazwani Baderol Sham. (2018). Perjalanan yang masih berliku. Dewan Bahasa, Julai, 6-9.

Arina Johari, Nurul Jamilah Rosly, Sara Beden \& Norlela Abdollah. (2018). Strategi Kesantunan Berbahasa untuk Penutur Asing. DIm. Nuraihan Mat Daud (Peny.), Bahasa Melayu untuk penutur asing (hlm. 106-117). Kuala Lumpur, Malaysia: Dewan Bahasa dan Pustaka.

Asmah Omar. (1996). Wacana, perbincangan, perbahasan dan perundingan. Kuala Lumpur, Malaysia: Dewan Bahasa dan Pustaka.

Asmah Omar. (2000). Wacana, perbincangan, perbahasan dan perundingan. Kuala Lumpur, Malaysia: Dewan Bahasa dan Pustaka.

Asmah Omar. (2007). Kesantunan bahasa dalam pengurusan pentadbiran dan media. Kuala Lumpur, Malaysia: Dewan Bahasa dan Pustaka.

Grice, H.P. (1975). Logic and conversations. DIm. P. Cole \& Morgan (Eds.), Syntax and semantic: speech act (hlm. 41-58). New York, NY: Academic Press. 
Hashim Ahmad (2016). Bahasa menggambarkan peribadi. Dewan Bahasa, Julai, 1014.

Jeniri Amir. (2009). Bahasa negara dan bangsa. Kuala Lumpur, Malaysia: Dewan Bahasa dan Pustaka.

Kamus Dewan Edisi Ketiga. (2000). Kuala Lumpur: Dewan Bahasa dan Pustaka.

Kamus Dewan Edisi Keempat. (2007). Kuala Lumpur: Dewan Bahasa dan Pustaka

Leech, G. (1983). Principles of pragmatics. London: Longman.

Leech, G. (1993). Prinsip pragmatik. (Terj.) Azhar M. Simin. Kuala Lumpur, Malaysia: Dewan Bahasa dan Pustaka.

Mohd Fahmi Mohamed Zaki. (2011). Bahasa santun, bangsa bertamadun. Dewan Bahasa, Februari, 14-17.

Mohamad Syafiq Rohaizad Buyong. (2018). Perjuangan bahasa Melayu di tangan anak muda. Dewan Bahasa, Julai, 10-14.

Norazlina Mohd Kiram \& Raja Masittah Raja Ariffin. (2012). Kesantunan berbahasa orang Melayu menerusi gaya pengurusan air muka dalam Saga: Aplikasi teori Ting-Toomey. Jurnal Bahasa, 12(2), 284-300.

Noriati Abd. Rashid. (2005). Nilai kesantunan dalam konteks sosiobudaya masyarakat Melayu. Jurnal Pengajian Melayu, 15, 232-253.

Robert Sibarani. (2004). Fenomena Kesantunan Berbahasa dalam Bahasa Indonesia/Melayu. Dlm. Worawit Baru @ Haji Ahmad Idris (Peny.), Dlm. Pemikiran Melayu tradisi dan kesinambungan (hlm. 215-228). Kuala Lumpur, Malaysia: Dewan Bahasa dan Pustaka.

Sara Beden \& Indirawati Zahid. (2014). Analisis kesopanan bahasa Leech \& Grice: Manifestasi struktur dalam peristiwa Melunas Rindu. Jurnal JATI, 19, 151168.

Sara Beden \& Indirawati Zahid. (2015). Paparan kesopanan berbahasa dalam teks Komsas Melunas Rindu: Aplikasi model Leech (1983) dan Grice (1975). Issues in Language Studies, 4(2), 41-62.

Sara Beden \& Indirawati Zahid. (2016). Pemetaan struktur peristiwa bahasa: Komunikasi bebas konflik. GEMA Online, Journal of Language Studies, 16(1), 67-87.

Sara Beden. (2018). Kesantunan bahasa penulisan. Dewan Bahasa, September, 5458.

Siti Hajar Abdul Aziz. (2009). Siri pendidikan guru bahasa Melayu II. Selangor, Malaysia: Oxford Fajar Sdn. Bhd.

Tenas Effendy. (2010). Kearifan pemikiran Melayu. Pekanbaru, Indonesia: Pemerintah Kota Pekanbaru \& Tenas Effendy Foundation.

Tenas Effendy (2011). Tenas Effendy. (2011). Kesantunan dan semangat Melayu. Pekanbaru, Indonesia: Pemerintah Kota Pekanbaru \& Tenas Effendy Foundation.

Yule, G. (1996). Pragmatics. Oxford, UK: Oxford University.

Zainal Abdidin Ahmad (Za'ba). (1950). Malay manners and etiquette. JMBRAS, XXIII.

Zaitul Azma Zainon Hamzah. (2009). Akhlak mulia melalui kesantunan berbahasa. Dewan Bahasa, September, 28-31. 